\title{
Napawanie wiązką elektronów przy użyciu drutu
}

\author{
Electron beam cladding with wire
}

\section{Streszczenie}

Celem pracy było przeprowadzenie badań w zakresie napawania przy użyciu wiązki elektronów i materiału dodatkowego w postaci drutu. Zakres pracy obejmował zbadanie wpływu warunków technologicznych tj.: prędkości podawania drutu, natężenia prądu wiązki, prędkości przesuwu, napięcia przyspieszającego na stabilność procesu napawania oraz wymiarów geometrycznych napoin. Przeprowadzone badania wykazały, iż przy niskim natężeniu prądu wiązki proces napawania nie jest stabilny. Nadlew nie jest równomierny, można zaobserwować nierównomierność szerokości, wysokości i prostoliniowości nadlewu. Przy zbyt wysokim napięciu przyspieszającym oraz natężeniu prądu wiązki można zaobserwować przetopienie płyty próbnej na wskroś i wyciek w grani. Przeprowadzone badania wykazały również, iż wzrost prędkości napawania (przesuwu stołu) powoduje zmniejszenie szerokości lica oraz wysokości nadlewu.

Słowa kluczowe: napawanie wiązką elektronów; inżynieria powierzchni

\section{Abstract}

The aim of the presented work was to carry out the research on electron beam cladding with a wire as a filler material. The scope of the work was to investigate the influence of technological parameters such as: wire feed rate, beam current, travelling speed, acceleration voltage on stability of the cladding process and geometric dimensions of the padding welds. The research revealed that, at low beam currents, the cladding process is unstable. The padding weld reinforcement is non-uniform. Irregularity of the width, height and straightness of the padding welds can be observed. At too high acceleration voltage and beam current, burn-through of plate and excess penetration weld can be revealed. The study also showed that increase of the cladding rate (travelling speed on the table) results in reduced face width and padding weld reinforcement.

Keywords: electron beam cladding; surface engineering

\section{Wprowadzenie}

Biorąc pod uwagę stale rosnące wymagania wobec materiałów, elementów i narzędzi w zakresie trwałości, poprawy własności użytkowych i obniżenia kosztów produkcji, inżynieria powierzchni jest prężnie rozwijającą się dziedziną nauki i techniki. Wśród wielu stosowanych technologii spawalniczych, które mogą być wykorzystywane do wykonywania warstw o unikalnych własnościach, są również technologie elektronowe, które głównie są stosowane do łączenia elementów [1,2]. Wysoka gęstość energii, precyzja prowadzenia procesu, atmosfera ochronna w postaci próżni powoduje, że proces ten $w$ wielu przypadkach jest jedynym rozwiązaniem, jakie może być zastosowane lub też, który zapewni najwyższe oczekiwane własności użytkowe modyfikowanych powierzchni. W przypadku braku możliwości prowadzenia procesów w próżni można zastosować urządzenia z częściową próżnią lub bezpróżniowe [3].

Proces napawania przy wykorzystaniu wiązki elektronów jest unikatową technologią umożliwiającą wprowadzenie bezpośrednio do jeziorka ciekłego metalu materiału dodatkowego w postaci proszku lub drutu. Dodatkowo możliwa jest rafinacja ciekłego metalu, gdyż proces prowadzony jest w próżni (rys. 1).

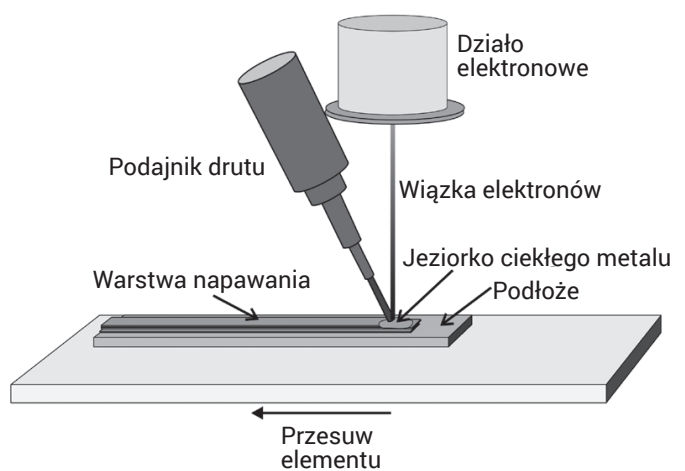

Rys. 1. Schemat procesu napawania wiązką elektronów przy użyciu drutu

Fig. 1. Scheme of electron beam cladding process using wire

Dr inż. Marek St. Węglowski, mgr inż. Sylwester Błacha - Instytut Spawalnictwa.

Autor korespondencyjny/Corresponding author: marek.weglowski@is.gliwice.pl 
Nowoczesne urządzenia zapewniają precyzyjną regulację parametrów wiązki, takich jak np. moc wiązki, czy wielkość ogniska. Jest to szczególnie ważne w celu zapewnienia minimalnego wtopienia, minimalnej objętości stopionego metalu, a z drugiej strony wykorzystania energii wiązki o gęstości aż do $10^{12} \mathrm{~W} / \mathrm{m}^{2}$. Procesy napawania mogą być prowadzone w jednym przejściu lub też wielokrotnie co umożliwia optymalizację składu chemicznego i własności uzyskanych warstw [4].

Podobnie jak w przypadku napawania wiązką laserową, technologia wykorzystująca skoncentrowaną wiązkę elektronów zapewnia $[5,6]$ :

- możliwość wykonywania napoin z materiałów znacznie różniących się składem chemicznym;

- bardzo mały udział metalu podłoża w napoinie;

- bardzo dużą dokładność i powtarzalność napawanych przedmiotów o niemal dowolnym kształcie powierzchni roboczej;

- układanie bardzo cienkich warstw o grubości od 0,1 mm; grubsze warstwy uzyskuje się poprzez napawanie wielowarstwowe;

- bardzo małe oddziaływanie cieplne na napawany materiał, minimalne naprężenia i odkształcenia spawalnicze;

- łatwość automatyzacji.

Należy zwrócić uwagę na fakt, iż w porównaniu do procesu napawania przy użyciu wiązki laserowej nie ma konieczności stosowania i pozycjonowania dysz doprowadzających gaz osłonowy.

Napawanie wiązką elektronów z materiałem dodatkowym, w postaci drutu jest procesem trudniejszym technicznie w porównaniu do przetapiania powierzchni. Konieczne jest zapewnienie stabilności procesu napawania poprzez precyzyjny dobór szeregu parametrów technologicznych. Na rysunku 2 przedstawiono geometrię wzajemnego usytuowania końcówki drutu względem wiązki elektronów oraz techniki podawania materiału dodatkowego.

Głównymi parametrami technologicznymi procesu napawania wiązką elektronów są: napięcie przyspieszające, natężenie prądu wiązki, prędkość przesuwu, średnica wiązki na powierzchni elementu napawanego, ciśnienie (próżnia) wewnątrz komory, prędkość podawania drutu, kąt wprowadzania drutu, długość wolnego wylotu, położenie końcówki drutu względem wiązki elektronów i jeziorka ciekłego metalu (rys. 2a), sposób podawania drutu (rys. 2b).

Proces napawania wiązką elektronów może być prowadzony przy użyciu drutów litych oraz proszkowych. W przypadku drutów proszkowych zbyt duża ilość wydzielanych

a)

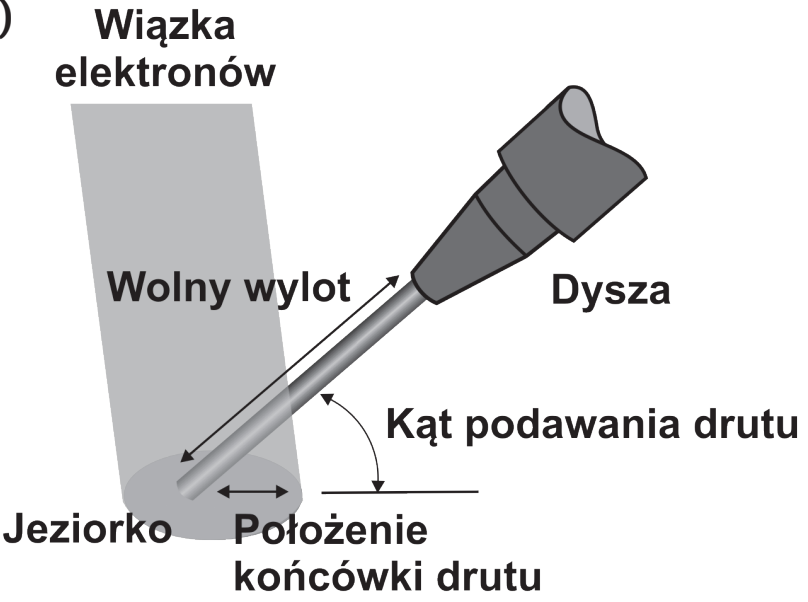

gazów powoduje zakłócenia w procesie napawania. Nie ma możliwości prowadzenia procesu napawania wiązką elektronów drutami proszkowymi samoosłonowymi.

Napawanie przy użyciu wiązki elektronów jest szczególnie przydatne do napawania stalami stopowymi, odpornymi na korozję oraz metalami reaktywnymi. Morimoto i inni [8] przedstawili wyniki badań procesu napawania stali austenitycznej X6CrNiMoTi17-12-2 i stali duplex X2CrNiMoN22-5-3 dwoma drutami: $\mathrm{Fe}-79,2 \%, \mathrm{C}-0,4 \%, \mathrm{Cr}-17,9 \%$, Mo - 1,2\%, $\mathrm{Si}<1 \%, \mathrm{Mn}-0,7 \%$ i Co $-59,2 \%, \mathrm{C}-1,8 \%, \mathrm{Cr}-31 \%$, W $-8 \%$. Proces napawania pozwolił uzyskać wzrost twardości warstwy napawanej do $550 \mathrm{HV} 0,3$ oraz wzrost odporności na korozję. Również Jung i inni [9] wykazali, że napawanie wiązką elektronów stali stopowej X6CrNiMoTi17-12-2 oraz stali dupleks X2CrNiMoN22-5-3 umożliwia wzrost odporności na zużycie w warunkach tarcia przy zachowaniu odporności na korozję.

Proces napawania wiązką elektronów może być wykorzystany do naprawy uszkodzonych elementów maszyn. Richter i inni [10] przeprowadzili proces napawania wiązką elektronów drutem w gatunku CORODUR 300 wału wykonanego ze stali ulepszanej cieplnie 34CrMo4.

Proces napawania wiązką elektronów może być prowadzony przy użyciu taśmy lub folii. Ważnym jednak jest precyzyjny dobór warunków technologicznych procesu, tak by nie następowało wymieszanie materiału dodatkowego $z$ materiałem podłoża [11]. La Barbera i inni [12] przedstawili wyniki badań procesu napawania wiązką elektronów stali niestopowej przy użyciu taśmy ze stali X5CrNiMo17-12-2. Badania obejmowały określenie wpływu procesu napawania na odporność korozyjną, budowę mikrostrukturalną oraz własności mechaniczne. Badania potwierdziły, że zastosowanie zbyt dużej gęstości mocy powoduje nadmierne wymieszanie z materiałem podłoża, rozpuszczenie składników stopowych co powoduje występowanie przemiany martenzytycznej. Mikrostruktura warstwy napawanej składała się z ferrytu-delta, austenitu oraz martenzytu. W mikrostrukturze zidentyfikowano również węgliki typu $\mathrm{M}_{6} \mathrm{C}$. Przeprowadzone badania wykazały zmniejszenie odporności na korozję warstwy napawanej w porównaniu do stali X5CrNiMo17-12-2 oraz wzrost twardości. Proces napawania wiązką elektronów w próżni jest szczególnie użyteczny w przypadku napawania materiałów ze stopów reaktywnych, takich jak: tytan, niob, molibden. W pracy [11] przedstawiono wyniki napawania stali stopowej X5CrNi18-10 o grubości $3 \mathrm{~mm}$ taśmą tytanową o grubości od 0,1 do 0,3 mm. Autorzy wykazali, że precyzyjne kontrolowanie gęstości energii jest sprawą

b)

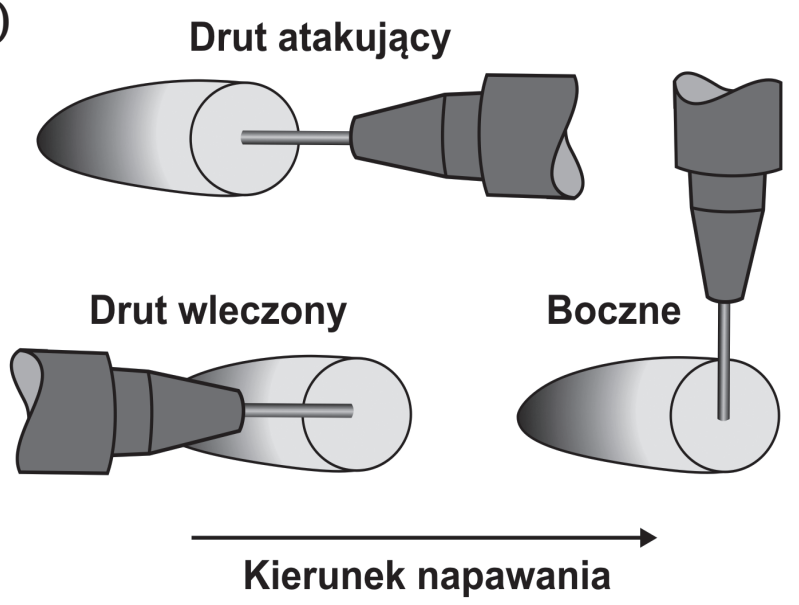

Rys. 2. a) schemat wzajemnego usytuowania końcówki materiału dodatkowego względem wiązki elektronów, b) techniki wprowadzania materiału dodatkowego [7]

Fig. 2. a) scheme of the mutual position of the tip of the additive material to the electron beam, b) the techniques of introducing the filler material [7] 
zasadniczą przy napawaniu cienkimi taśmami. Właściwą jakość warstwy napawanej uzyskano przy gęstości energii w zakresie od 0,05 do 0,12 kW/ $\mathrm{mm}^{2}$.

W pracy przedstawiono wyniki badań procesu napawania drutem ze stali stopowej. Zakres pracy obejmował zbadanie wpływu warunków technologicznych procesu tj.: prędkość podawania drutu, natężenie prądu wiązki, prędkość przesuwu, napięcie przyspieszające na stabilność procesu napawania oraz geometrię napoin.

\section{Metodyka badań}

Próby napawania były prowadzone na płytach próbnych o wymiarach 200 × 80 × 10 mm ze stali niestopowej w gatunku S355JR. Powierzchnia płyt przed napawaniem została wstępnie sfrezowana oraz oczyszczona przy użyciu acetonu. Jako materiał dodatkowy został wykorzystany drut o średnicy 1,2 mm ze stali stopowej w gatunku LNM307 (Lincoln Electric) - stal typu 18-8. Badania technologiczne były przeprowadzone przy użyciu urządzenia do spawania i modyfikowania powierzchni model XW150:30/756 (Cambridge Vacuum Engineering). Urządzenie zostało wyposażone w podajnik drutu umożliwiający wykorzystywanie materiałów dodatkowych w postaci szpuli o wadze do $15 \mathrm{~kg}$. Badania przeprowadzono przy stałym pozycjonowaniu końcówki drutu względem wiązki elektronów. Kąt podawania drutu wynosił $30^{\circ}$, a ciśnienie wewnątrz komory było na poziomie $5 \cdot 10^{-5} \mathrm{mbar}$, natężenie prądu wiązki wynosiło od 1 do $30 \mathrm{~mA}$, napięcie przyspieszające wynosiło od 60 do $150 \mathrm{kV}$, prędkość podawania drutu wynosiła od 600 do $3600 \mathrm{~mm} / \mathrm{min}$, a prędkość przesuwu stołu wynosiła od 200 do 7000 mm/min.

\section{Wyniki badań i analiza}

Celem pracy było określenie wpływu wybranych warunków technologicznych napawania przy użyciu wiązki elektronów na szerokość lica i wysokość nadlewu. Badania prowadzono dla jednego materiału dodatkowego w gatunku LNM307.

W pierwszym etapie określono wpływ prędkości podawania drutu na szerokość lica oraz wysokość nadlewu. Badania przeprowadzono przy stałej wartości natężenia prądu wiązki I = 5, 15 i $30 \mathrm{~mA}$ oraz stałej wartości napięcia przyspieszającego $U=60,80,100,120$ i 150 kV. Prędkość przesuwu stołu była stała i wynosiła $\mathrm{V}_{\mathrm{s}}=800 \mathrm{~mm} / \mathrm{min}$. $\mathrm{Na}$ podstawie zebranych danych eksperymentalnych opracowano zależności empiryczne pomiędzy prędkością podawania drutu a szerokością lica oraz wysokością nadlewu przy stałym napięciu przyspieszającym i stałym natężeniu prądu wiązki. Na rysunkach 3 i 4 przedstawiono wpływ prędkości podawania drutu $V_{d}$ na wysokość nadlewu h i szerokość lica b odpowiednio dla $U=60 \mathrm{kV}$ (rys. 3) i U = $150 \mathrm{kV}$ (rys. 4) oraz dla $\mathrm{V}_{\mathrm{s}}=800 \mathrm{~mm} / \mathrm{s}$.

Analiza danych wykazała, iż dla stałej mocy wiązki i prędkości przesuwu dla procesu napawania wiązką elektronów przy użyciu drutu możliwe jest określenie parametrów technologicznych, dla których proces napawania przebiega stabilnie. Przy zbyt małych prędkościach podawania drutu zaobserwowano, że proces jest niestabilny. Zbyt duża moc wiązki elektronów topi materiał dodatkowy na większym odcinku oraz w większym stopniu oddziałuje na materiał podstawowy. Może to spowodować przerywanie tworzącego się mostka ciekłego metalu, tworzenie się kropli na końcówce drutu i chwilowe zaburzenie stabilności procesu napawania analogicznie jak przy napawaniu laserowym [13]. Zaburzenia te można zaobserwować dla napoin przedstawionych na rysunku 5 .

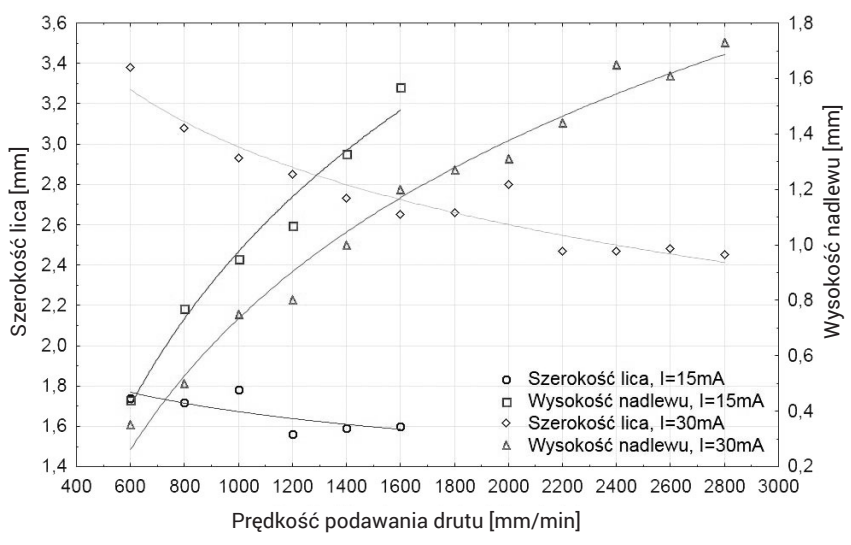

Rys. 3. Wpływ prędkości podawania drutu $V_{d}$ na wysokość nadlewu h i szerokość lica b dla $U=60 \mathrm{kV}, \mathrm{V}_{\mathrm{s}}=800 \mathrm{~mm} / \mathrm{s}$

Fig. 3. Influence of the wire feed rate $V_{d}$ on the padding weld height $\mathrm{h}$ and face width $\mathrm{b}$ for $\mathrm{U}=60 \mathrm{kV}, \mathrm{V}_{\mathrm{s}}=800 \mathrm{~mm} / \mathrm{s}$

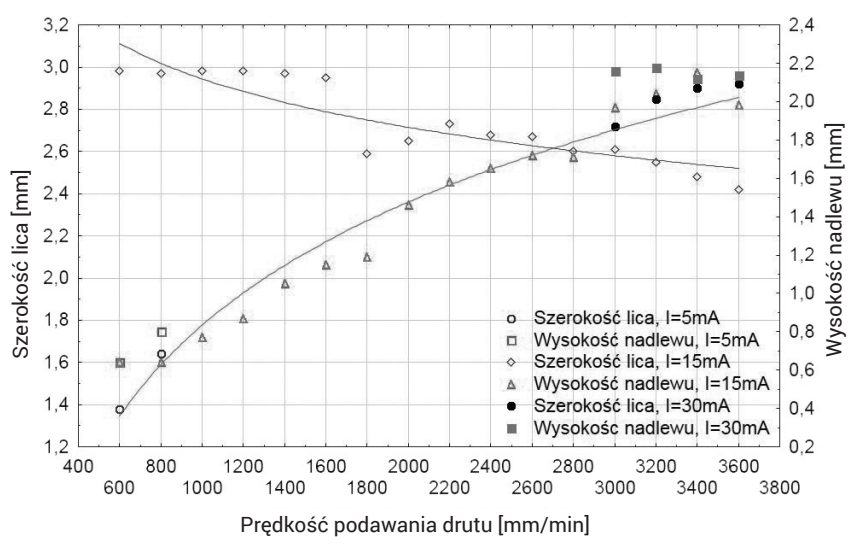

Rys. 4. Wpływ prędkości podawania drutu $V_{d}$ na wysokość nadlewu h i szerokość lica b dla $U=150 \mathrm{kV}, \mathrm{V}_{\mathrm{s}}=800 \mathrm{~mm} / \mathrm{s}$

Fig. 4. Influence of the wire feed rate $V_{d}$ on the padding weld height $\mathrm{h}$ and face width $\mathrm{b}$ for $\mathrm{U}=150 \mathrm{kV}, \mathrm{V}_{\mathrm{s}}=800 \mathrm{~mm} / \mathrm{s}$

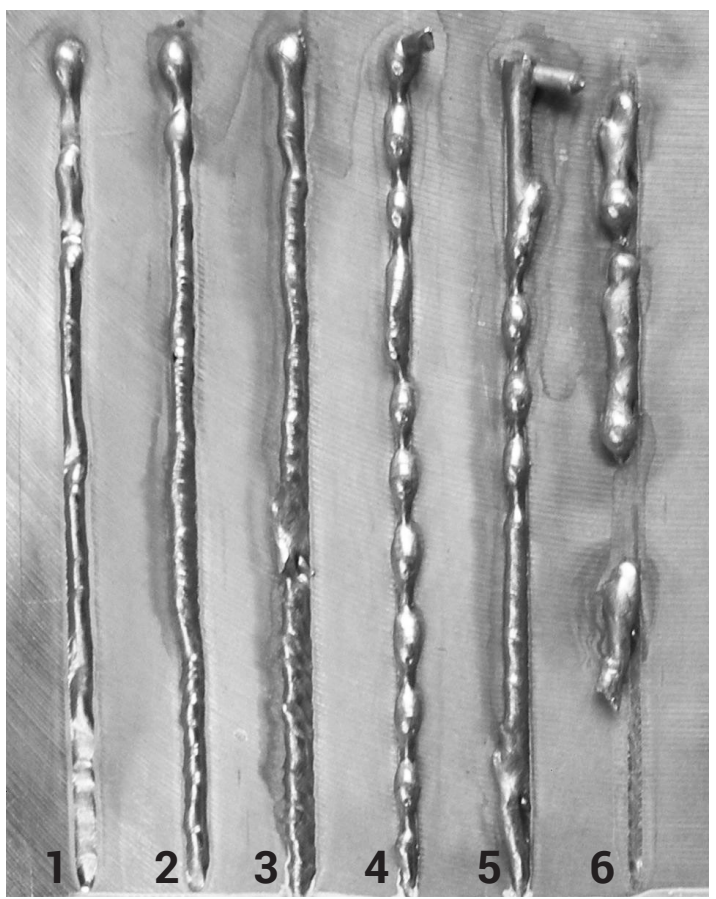

Rys. 5. Widok napoin uzyskanych dla różnych prędkości podawania drutu: $1-600 \mathrm{~mm} / \mathrm{min}, 2-700 \mathrm{~mm} / \mathrm{min}, 3-800 \mathrm{~mm} / \mathrm{min}$, 4- $900 \mathrm{~mm} / \mathrm{min}, 5-1000 \mathrm{~mm} / \mathrm{min}, 6-1100 \mathrm{~mm} / \mathrm{min}$ przy napięciu przyspieszającym $U=80 \mathrm{kV}$ i natężeniu prądu wiązki I $=5 \mathrm{~mA}$

Fig. 5. View of the padding welds obtained for different feed rates of wire: $1-600 \mathrm{~mm} / \mathrm{min}, 2-700 \mathrm{~mm} / \mathrm{min}, 3-800 \mathrm{~mm} / \mathrm{min}$, $4-900 \mathrm{~mm} / \mathrm{min}, 5-1000 \mathrm{~mm} / \mathrm{min}, 6-1100 \mathrm{~mm} / \mathrm{min}$ with the accelerating voltage $U=80 \mathrm{kV}$ and the beam current $\mathrm{I}=5 \mathrm{~mA}$ 
Przy zbyt dużej prędkości podawania drutu, ilość dostarczanej energii jest niewystarczająca do stabilnego procesu stapiania drutu. Drut jest głębiej wprowadzany do obszaru oddziaływania wiązki elektronów i ogranicza możliwość tworzenia kanału gazodynamicznego. Zwiększona objętość materiału dodatkowego zalewa tworzący się kanał oraz powoduje, że samo jeziorko jest większe. Nadmiar materiału dodatkowego powoduje ponadto, iż ciekły metal wypychany jest w niekontrolowany sposób, tworząc nadmierny nadlew (rys. 6). Przy napięciu przyspieszającym 120 kV nierównomierność wysokości nadlewu zaobserwowano przy prędkości podawania drutu od $V_{d}=3000 \mathrm{~mm} / \mathrm{min}$.

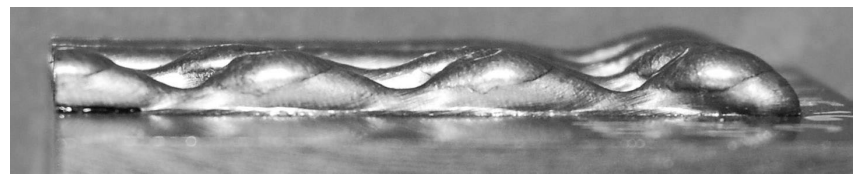

Rys. 6. Nierównomierność wysokości nadlewu spowodowana zbyt dużą prędkością podawania drutu, $\mathrm{V}_{\mathrm{d}}=3600 \mathrm{~mm} / \mathrm{min}, \mathrm{U}=120 \mathrm{kV}$, $\mathrm{I}=15 \mathrm{~mA}, \mathrm{~V}_{\mathrm{s}}=800 \mathrm{~mm} / \mathrm{min}$

Fig. 6. Unevenness of the padding weld height caused by too high wire feed rate, $V_{d}=3600 \mathrm{~mm} / \mathrm{min}, \mathrm{U}=120 \mathrm{kV}, \mathrm{I}=15 \mathrm{~mA}, \mathrm{~V}_{\mathrm{s}}=800 \mathrm{~mm} / \mathrm{min}$

Przeprowadzone badania wykazały, iż materiał dodatkowy w postaci drutu podawany do obszaru napawania w znacznym stopniu zużywany jest na wytworzenie nadlewu, którego wysokość wzrasta wraz ze wzrostem prędkości podawania drutu. Jednak, w przypadku gdy napięcie przyspieszające osiąga wartość $150 \mathrm{kV}$, a natężenie prądu wiązki 30 mA moc wiązki jest na tyle duża, że następuje przetopienie na wskroś płyty próbnej (o grubości $10 \mathrm{~mm}$ ) i wyciek materiału dodatkowego oraz podstawowego poza obszar grani (rys. 7).

W drugim etapie prowadzonych badań określono wpływ zmiany natężenia prądu wiązki na szerokość lica oraz wysokość nadlewu (rys. 8 i 9) przy stałej wartości prędkości podawania drutu $V_{d}=1000 \mathrm{~mm} / \mathrm{min}$ i stałej wartości napięcia przyspieszającego $U=60,80,100,120$ i 150 kV. Prędkość przesuwu stołu była stała i wynosiła $V_{s}=800 \mathrm{~mm} / \mathrm{min}$. Analiza zebranych danych pomiarowych wykazała, iż przy niskim natężeniu prądu wiązki przy stałym napięciu przyspieszającym proces napawania nie jest stabilny. Nadlew nie jest równomierny i można zaobserwować nierównomierność szerokości, wysokości i prostoliniowości nadlewu [13]. Jest to spowodowane zbyt małą mocą wiązki. Zbyt mała energia jest dostarczana na stopienie materiału dodatkowego oraz podłoża. W przypadku gdy wzrasta napięcie przyspieszające, minimalna wartość natężenia prądu wiązki przy której proces jest stabilny maleje. Przykładowo przy napięciu przyspieszającym $60 \mathrm{kV}$, proces napawaniajest stabilny dla I > $10 \mathrm{~mA}$, a przy U $=150 \mathrm{kV}$, dla I > $7 \mathrm{~mA}$. Dalszy wzrost natężenia prądu wiązki powoduje wzrost szerokości lica (rys. 8). Jednak można zauważyć, iż wraz ze wzrostem natężenia prądu, wzrost szerokości lica jest coraz mniejszy. Jest to związane z faktem, iż wraz ze wzrostem natężenia prądu rośnie głębokość wtopienia i rośnie udział materiału dodatkowego w obszarze materiału podstawowego. Przy zbyt dużym natężeniu prądu wiązki (przy I = 28 i 30 mA, $\mathrm{U}=150 \mathrm{kV}$ ) zaobserwowano, że szerokość lica maleje i następuje przetopienie płyty próbnej na wskroś oraz wyciek stopionego materiału poza obszar grani.

Analizując dane przedstawione na rysunku 8, można ponadto zauważyć, iż wraz ze wzrostem napięcia przyspieszającego rośnie szerokość lica. Wzrost napięcia przyspieszającego (podobnie jak wzrost natężenia prądu wiązki) powoduje wzrost prędkości elektronów i wzrost ich energii kinetycznej. Większa energia dostarczana do materiału dodatkowego powoduje, iż ciekły materiał jest „rozprowadzany" po większej powierzchni nagrzanej do wyższej temperatury, nie ma efektu ograniczania szerokości lica spowodowanego zjawiskiem Leidenfrosta [7].

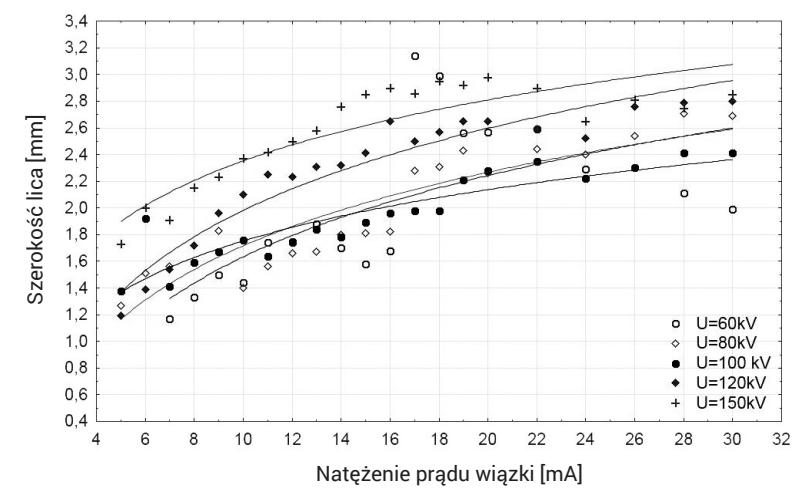

Rys. 8. Wpływ natężenia prądu wiązki na szerokość lica b dla $V_{d}=1000 \mathrm{~mm} / \mathrm{min}, \mathrm{V}_{\mathrm{s}}=800 \mathrm{~mm} / \mathrm{min}$

Fig. 8. Influence of beam current on the face width $b$ for $\mathrm{V}_{\mathrm{d}}=1000 \mathrm{~mm} / \mathrm{min}, \mathrm{V}_{\mathrm{s}}=800 \mathrm{~mm} / \mathrm{min}$

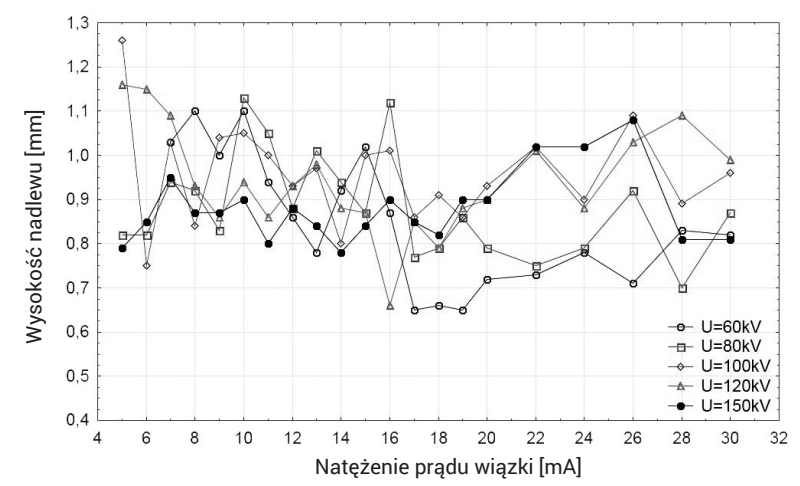

Rys. 9. Wpływ natężenia prądu wiązki na wysokości nadlewu $h$ dla $V_{d}=1000 \mathrm{~mm} / \mathrm{min}, V_{\mathrm{s}}=800 \mathrm{~mm} / \mathrm{min}$

Fig. 9. Influence of beam current on the padding weld height $h$ for $V_{d}=1000 \mathrm{~mm} / \mathrm{min}, V_{s}=800 \mathrm{~mm} / \mathrm{min}$

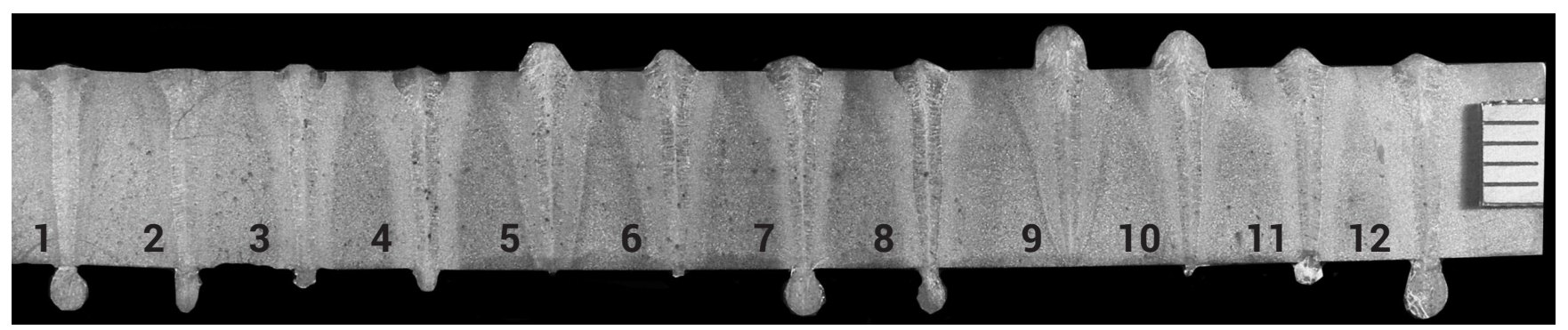

Rys. 7. Makrostruktura napoin uzyskanych dla różnych prędkości podawania drutu: 1 - 600, 2 - 800, 3 - 1000, 4 - 1200, 5 - 1400, 6 - 1600, $7-1800,8-2000,9-2200,10-2400,11-2600,12-2800 \mathrm{~mm} / \mathrm{min}, \mathrm{U}=150 \mathrm{kV}, \mathrm{I}=30 \mathrm{~mA}$

Fig. 7. Macrostructure of the padding welds obtained for different feed rates of wire: $1-600,2-800,3-1000,4-1200,5-1400,6-1600$, $7-1800,8-2000,9-2200,10-2400,11-2600,12-2800 \mathrm{~mm} / \mathrm{min}, \mathrm{U}=150 \mathrm{kV}, \mathrm{I}=30 \mathrm{~mA}$ 
Przeprowadzone badania wykazały ponadto, że nie ma wyraźnego związku pomiędzy natężeniem prądu wiązki a wysokością nadlewu (rys. 9). Przy niskich napięciach przyspieszającychU $=60 \mathrm{i} 80 \mathrm{kV}$ zaobserwowano zmniejszenie wysokości nadlewu wraz ze wzrostem natężenia prądu, natomiast przy wyższych napięciach przyspieszających następuje wzrost wysokości nadlewu.

Jednym z parametrów technologicznych mogących znacząco wpływaćna geometrięnapoin, ajednocześniemającym wpływ na koszty napawania jest prędkość napawania (prędkość przesuwu). W pracy wpływ prędkości przesuwu stołu

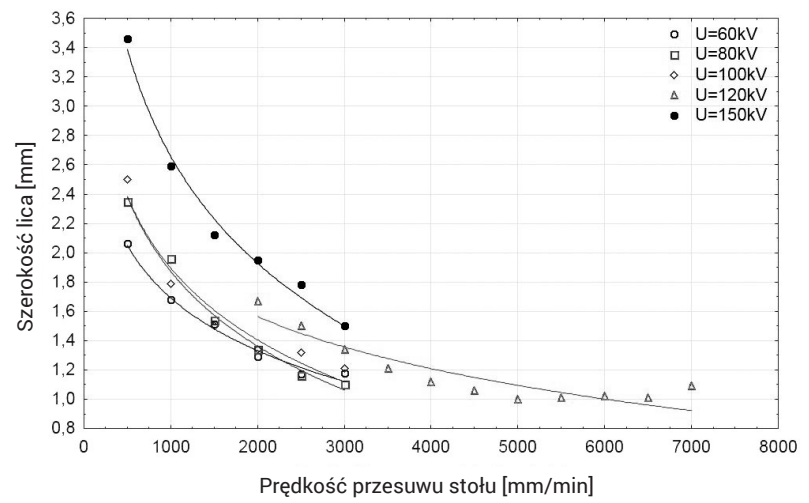

Rys. 10. Wpływ prędkości przesuwu stołu na szerokość lica dla I $=15 \mathrm{~mA}, V_{d}=1000 \mathrm{~mm} / \mathrm{min}$

Fig. 10. Influence of the table travelling speed on the face width for $\mathrm{I}=15 \mathrm{~mA}, \mathrm{~V}_{\mathrm{d}}=1000 \mathrm{~mm} / \mathrm{min}$ na wysokość nadlewu i szerokość lica (rys. 10 i 11) wyznaczono przy stałej wartości natężenia prądu wiązki I=15 mA i napięciu przyspieszającym $U=60,80,100,120$ i $150 \mathrm{kV}$. Prędkość podawania drutu wynosiła $V_{d}=1000 \mathrm{~mm} / \mathrm{min}$. Przeprowadzone badania wykazały, iż wzrost prędkości przesuwu stołu powoduje zmniejszenie szerokości lica oraz wysokości nadlewu. Jest to związane z faktem, iż wraz ze zwiększeniem prędkości przesuwu stołu w jednostce czasu do obszaru napawania wprowadzana jest mniejsza ilość materiału dodatkowego, a co za tym idzie maleje objętość napoiny.

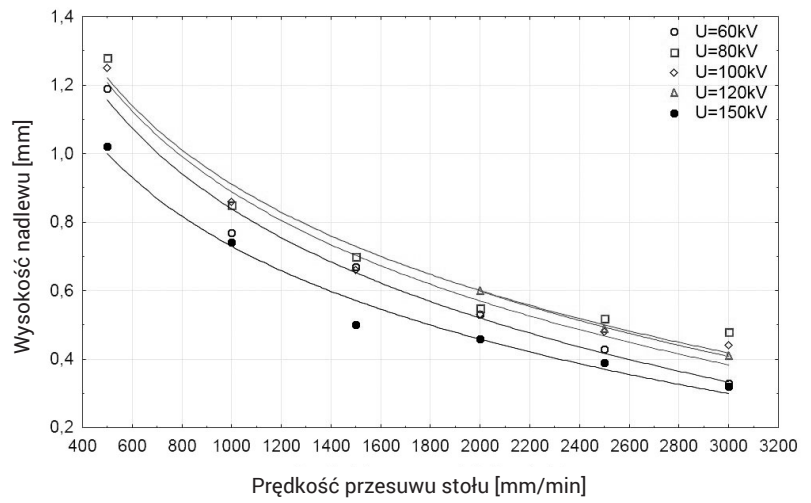

Rys. 11. Wpływ prędkości przesuwu stołu na wysokość nadlewu dla I $=15 \mathrm{~mA}, V_{d}=1000 \mathrm{~mm} / \mathrm{min}$

Fig. 11. Influence of the table travelling speed on the padding weld height for I $=15 \mathrm{~mA}, \mathrm{~V}_{\mathrm{d}}=1000 \mathrm{~mm} / \mathrm{min}$

\section{Wnioski}

Na podstawie przeprowadzonych badań można sformułować następujące wnioski:

- stabilny proces napawania wiązką elektronów przy użyciu drutu jest możliwy, jednak przy określonych warunkach technologicznych procesu w zależności od gatunku materiału dodatkowego;

- wzrost prędkości podawania drutu przy stałym napięciu przyspieszającym oraz natężeniu prądu wiązki powoduje wzrost wysokości nadlewu oraz zmniejszenie szerokości lica;

- wzrost natężenia prądu wiązki powoduje wzrost szerokości lica;

- wzrost prędkości napawania powoduje zmniejszenie szerokości lica oraz wysokości nadlewu;

- wzrost napięcia przyspieszającego powoduje wzrost szerokości lica oraz zmniejszenie wysokości nadlewu.

\section{Przedstawione badania zostały przeprowadzone w ramach działalności statutowej Instytutu Spawalnictwa finansowanej przez Ministerstwo Nauki i Szkolnictwa Wyższego}

\section{Literatura}

[1] M.St. Węglowski, J. Dworak, S. Błacha: Spawanie wiązką elektronów - charakterystyka metody, Biuletyn Instytutu Spawalnictwa, vol. 5, nr 3, s. 25-32, 2014.

[2] J. Pilarczyk, M.St. Węglowski: Wykorzystanie wiązki elektronów w spawaniu i technologiach pokrewnych, Biuletyn Instytutu Spawalnictwa, vol. 58, nr 5, s. 81-87, 2014.

[3] M.St. Weglowski, J. Dworak, S. Błacha: Spawanie wiązką elektronów - urządzenia, Biuletyn Instytutu Spawalnictwa, vol. 58, nr 4, s. 46-52, 2014.

[4] P. Adamiec, J. Dziubiński: Wytwarzanie i właściwości warstw wierzchnich elementów maszyn transportowych, Wydawnictwo Politechniki Śląskiej, Gliwice, 2005.

[5] J. Dworak, M. Banasik, S. Stano: Napawanie laserowe - możliwości technologiczne procesu, Seminarium Instytutu Spawalnictwa pt. Nowoczesne technologie spajania - praktyczne zastosowania przemysłowe, Gliwice, 2013.

[6] M. Banasik, J. Dworak, S. Stano: Spajanie laserowe ze spoiwem - technologie i zakres zastosowań, Seminarium Instytutu Spawalnictwa pt. Nowoczesne technologie spajania - praktyczne zastosowania przemysłowe, Gliwice, 2013.

[7] J. Zhao, B. Zhang, A. Li, et al.: Effects of metal-vapor jet force on the physical behavior of melting wire transfer in electron beam additive manufacturing, Journal of Materials Processing Technology, vol. 220, pp. 243-250, 2015.
[8] J. Morimoto, N. Abe, F. Kuriyama, et al.: Formation of a $\mathrm{Cr} 3 \mathrm{C} 2 / \mathrm{Ni}-\mathrm{Cr}$ alloy layer by an electron beam cladding method and evaluation of the layer properties, Vacuum, vol. 62, pp. 203-210, 2001.

[9] A. Jung, R. Zenker, J. Gleißner, et al.: Elektronenstrahl-Randschichtbehandlung für die Herstellung verschleißbeständiger Auftragschichten auf nichtrostenden Stählen, Materialwissenschaft und Werkstofftechnik, vol. 45, s. 486-495, 2014.

[10] A. Richter, Th. Krüssel, C. Just: Deposition welding with the electron beam as repair technology, International electron Beam Welding Conference, Aachen, 2012.

[11] M. Tomie, N. Abe, M. Yamada, et al.: Electron Beam Cladding of Titanium on Stainless Steel Plate, Transactions of JWRI, vol. 19, pp. 51-55, 1990.

[12] A. La Barbera, A. Mignone, S. Tosto, et al.: Electron beam cladding and alloying of AISI 316 on plain carbon steel: microstructure and electrochemical corrosion behaviour, Surface and Coatings Technology, vol. 46, pp. 317-329, 1991.

[13] J. Pilarczyk, M. Banasik, S. Stano, J. Dworak: Badanie i opracowanie warunków technologicznych procesu spawania laserowego z materiałem dodatkowym w postaci drutu, Sprawozdanie Ci-19 z realizacji projektu badawczego nr N N503 241538, Instytut Spawalnictwa, 2012. 